\title{
HUBUNGAN ANTARA TINGKAT KECUKUPAN LEMAK TIDAK JENUH TUNGGAL, MINERAL, DAN STATUS GIZI DENGAN KEJADIAN HIPERTENSI PADA LANSIA DI POSBINDU PTM PUSKESMAS TAJUR KOTA TANGERANG
}

\section{Relationship between the Level of Monounsaturated Fat, Mineral, and Nutritional Status with the Incidence of Hypertension in Posbindu PTM Puskesmas Tajur Tangerang City}

\author{
Kristina Rosalia Pakpahan ${ }^{1}$, Nadiyah ${ }^{1 *}$, Harna ${ }^{1}$, Mertien Sa'pang ${ }^{1}$, Yulia Wahyuni ${ }^{1}$ \\ 'Universitas Esa Unggul \\ Jalan Arjuna Utara Nomor 9 Kebon Jeruk, Jakarta Barat, DKI Jakarta, Indonesia \\ *e-mail: nadiyah@esaunggul.ac.id
}

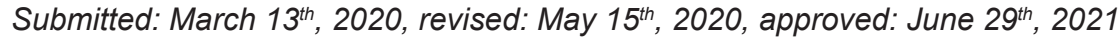

\begin{abstract}
Background. The hypertension can cause various related diseases. As you get older, the physiological function of the body also decrease and there are changes, especially in physiological changes, because with age, the function of organs will decreases both due to natural factors and due to disease. Hypertension is also often associated with nutritional status because someone who is overweight more likely to do hypertension than normal people. One of the most common health is problem of experienced by the elderly is reduced heart strength. The food intake is very important role to supporting healthy and blood pressure control. Objective. This study aim to determine the relationship between the adequacy level of monounsaturated fat, calcium, magnesium, potassium, and nutritional status with the incidence of hypertension in the elderly at Posbindu PTM Puskesmas Tajur Tangerang City. Method. The design of research used a cross-sectional design. The design was selected by proportional stratified random amounting to 108 respondents. Data analysis using Chi Square. Results. The findings showed that the adequacy level of monounsaturated fat (96.3\%), calcium (81.5\%), and potassium (54.6\%) was classified as low ( $<77 \%$ RDA) but the adequacy level of magnesium was sufficient (68.5\%) and most of them with overweight nutritional status (74\%). There was not relationship between the adequacy of monounsaturated fat, calcium, magnesium, potassium, and nutritional status with the incidence of hypertension ( $p>0.05$ ). Conclusion. There is no relationship between the adequacy of consumption of monounsaturated fat, calcium, magnesium, potassium, and nutritional status with the incidence of hypertension due to the hypertension at Posbindu PTM Puskesmas Tajur Tangerang City caused by many factors such as age, gender, education level, food intake, genetics, smoking habits, and stress. It is necessary to pay attention to intake supporting the health of the elderly people.
\end{abstract}

Keywords: hypertension, mineral, monounsaturated fatty acid, nutritional status

\begin{abstract}
ABSTRAK
Latar Belakang. Hipertensi dapat menyebabkan berbagai penyakit yang saling berhubungan. Semakin bertambahnya umur maka fungsi fisiologis tubuh juga semakin berkurang dan terjadi perubahan-perubahan terutama pada perubahan fisiologis karena dengan semakin bertambahnya umur, fungsi organ tubuh akan semakin menurun baik karena faktor alamiah maupun karena penyakit. Hipertensi juga sering dikaitkan dengan status gizi karena seseorang yang memiliki berat badan lebih cenderung mengalami hipertensi daripada orang dengan berat badan normal. Salah satu gangguan kesehatan yang paling banyak dialami oleh lansia yaitu berkurangnya kekuatan jantung. Asupan makan sangat berperan penting dalam menunjang kesehatan dan kontrol tekanan darah. Tujuan. Penelitian ini bertujuan untuk mengetahui hubungan tingkat kecukupan
\end{abstract}


lemak tidak jenuh tunggal, kalsium, magnesium, kalium, dan status gizi dengan kejadian hipertensi pada lansia di Posbindu PTM Puskesmas Tajur Kota Tangerang. Metode. Rancangan penelitian menggunakan desain cross-sectional. Rancangan dipilih secara proportional stratified random berjumlah 108 responden. Analisis data menggunakan Chi Square. Hasil. Hasil penelitian menunjukkan bahwa tingkat kecukupan lemak tidak jenuh tunggal (96,3\%), kalsium (81,5\%), dan kalium $(54,6 \%)$ tergolong kurang $(<77 \%$ AKG) namun untuk tingkat kecukupan magnesium tergolong cukup $(68,5 \%)$ dan sebagian besar responden dengan status gizi overweight $(74 \%)$. Oleh karena itu, tidak terdapat hubungan antara tingkat kecukupan lemak tidak jenuh tunggal, kalsium, magnesium, kalium, dan status gizi dengan kejadian hipertensi $(p>0,05)$. Kesimpulan. Tidak ada hubungan antara kecukupan konsumsi lemak tidak jenuh tunggal, kalsium, magnesium, kalium, dan status gizi dengan kejadian hipertensi pada lansia di Posbindu PTM Puskesmas Tajur Kota Tangerang. Akan tetapi kemungkinan disebabkan faktor resiko lain yang berhubungan dengan hipertensi yang tidak dianalisa dalam penelitian ini. Selain itu, perlu diperhatikan asupan untuk menunjang kesehatan lansia.

Kata kunci: hipertensi, mineral, lemak tidak jenuh tunggal, status gizi

\section{PENDAHULUAN}

Hipertensi adalah penyakit dengan jumlah penderita yang banyak dan diprediksi akan bertambah sampai 60 persen di tahun 2025 yaitu 1,56 miliar orang akan mengalami tekanan darah tinggi dan mengalami kenaikan dari tahun 2013 ke tahun 2018 yaitu 25,8 persen menjadi 34,1 persen. ${ }^{1,2,3}$ Penyakit kardiovaskular menjadi salah satu masalah kesehatan yang antara lain disebabkan gangguan pada dinding pembuluh darah yang akan menyebabkan pembuluh darah menjadi tidak elastis dan proses oksigenisasi menjadi berkurang sehingga terjadi hipertensi. ${ }^{4}$ Oleh karena itu, bertambahnya umur akan meningkatkan tekanan darah baik sistolik maupun diastolik. Berdasarkan data Riskesdas tahun 2018, prevalensi hipertensi berdasarkan hasil pengukuran, pada kelompok umur 3144 tahun sebesar 31,6 persen, pada umur 45-54 tahun sebesar 45,3 persen dan paling tinggi pada kelompok umur 55-64 tahun yaitu 55,2 persen. $^{2}$ Kelompok lanjut usia (lansia) merupakan kelompok yang paling rentan mengalami hipertensi.

Asupan makan berhubungan erat dengan kontrol tekanan darah. Selain natrium, banyak zat gizi dan mineral telah diteliti hubungannya dengan tekanan darah seperti makronutrien meliputi tingkat kecukupan protein, lemak, karbohidrat, serat, dan mikronutrien meliputi tingkat kecukupan kalsium, magnesium, kalium, vitamin C, dan vitamin D. ${ }^{5}$ Asupan lemak tidak jenuh tunggal dapat menurunkan kadar kolesterol low density lipoprotein (LDL), sehingga dapat menurunkan tekanan darah. ${ }^{6}$ Beberapa penelitian sebelumnya masih menunjukkan hasil yang berbeda. Penelitian pada penderita hipertensi di Malang menunjukkan bahwa jumlah dan jenis dari asupan lemak dapat memengaruhi tekanan darah. Penelitian pada wanita menopause di Semarang menunjukkan asupan lemak tidak jenuh tunggal tidak memiliki keterkaitan dengan kejadian hipertensi pada wanita menopause..$^{7,5}$

Asupan lemak tidak jenuh tunggal dan asupan kalsium memiliki fungsi dalam pengaturan tekanan darah, menurunkan aktivitas reninangiotensin, menaikkan keselarasan natrium dan kalium serta menghambat pembengkakan pembuluh darah. Jika makanan dan minuman yang dikonsumsi kurang, maka hormon tiroid melakukan stimulus untuk mengambil kalsium dari tulang serta dimasukkan ke dalam darah. Asam lemak bebas akan terikat oleh kalsium yang ada dalam darah sehingga mengurangi kelenturan jantung karena pembuluh darah menebal. ${ }^{8}$ Penelitian hipertensi di Yogyakarta menjelaskan tidak ada hubungan kalsium dan 
hipertensi. ${ }^{9}$ Berbeda dengan hasil penelitian Hasanah tentang asupan kalsium yang tidak signifikan dengan kejadian hipertensi. ${ }^{10}$

Asupan lemak tidak jenuh tunggal, kalsium, asupan kalium berhubungan dengan mekanisme penurunan tekanan darah dan menjaga keseimbangan cairan dalam tubuh. ${ }^{11}$ Penelitian Amran et al. yang mempelajari pengaruh tambahan asupan kalium dari diet terhadap penurunan hipertensi sistolik pada lansia menunjukkan ada pengaruh tambahan asupan kalium dengan penurunan tekanan darah sistolik. ${ }^{12}$ Berbeda dengan penelitian hipertensi lansia di Yogyakarta yang menyatakan tidak ada hubungan antara kalium dengan kejadian hipertensi pada lansia. ${ }^{13}$

Asupan lemak tidak jenuh tunggal, kalsium, kalium, dan magnesium adalah inhibitor pada kontraksi otot polos pembuluh darah dan berperan dalam pengaturan tekanan darah sebagai vasodilator. ${ }^{11,14}$ Penelitian hubungan konsumsi gizi di Semarang menyatakan ada hubungan asupan magnesium dengan kejadian hipertensi pada wanita menopause. ${ }^{15}$ Sebaliknya, penelitian dengan topik yang sama pada penelitian sebelumnya menyatakan tidak ada hubungan antara asupan magnesium dan hipertensi pada lansia. ${ }^{16}$

Hipertensi seringkali dikaitkan dengan status gizi, karena orang dengan kelebihan berat badan lebih berisiko mengalami hipertensi daripada orang dengan berat badan ideal karena lebih banyak melakukan aktivitas untuk melakukan proses pembakaran. ${ }^{17}$ Penelitian pada penderita hipertensi di Semarang menyatakan ada perbedaan asupan sumber lemak dan indeks massa tubuh dengan tekanan darah pada penderita hipertensi. ${ }^{18}$ Berbeda dengan penelitian hipertensi pada lansia di Minahasa yang menyatakan status gizi dan tekanan darah tidak memiliki hubungan yang signifikan. ${ }^{19}$

Berdasarkan latar belakang tersebut, peneliti tertarik ingin meneliti hubungan tingkat kecukupan lemak tidak jenuh tunggal, mineral, dan status gizi dengan kejadian hipertensi pada lansia di Posbindu PTM Puskesmas Tajur Kota Tangerang.

\section{METODE}

Penelitian ini merupakan jenis penelitian kuantitatif observasional dengan rancangan penelitian cross-sectional. Izin etik nomor 0515-19.493/DPKE-KEP/FINAL-EA/UEU/ $\mathrm{XI} / 2019$ diperoleh dari Universitas Esa Unggul. Lokasi penelitian di Posbindu Puskesmas Tajur Kota Tangerang pada bulan November 2019. Responden pada penelitian ini adalah lansia dengan umur 45-77 tahun, bersedia menjadi responden, dapat berkomunikasi dengan baik, aktif mengikuti kegiatan posbindu, memiliki riwayat hipertensi berdasarkan asesmen dokter dari posbindu, dan didiagnosis menderita hipertensi. Responden dipilih berdasarkan teknik proportional stratified random, diambil dari delapan posbindu yang ada di wilayah kerja Puskesmas Tajur Kota Tangerang, dan diperoleh sebanyak 108 orang lansia.

Pengumpulan data dilakukan dengan wawancara menggunakan semi quantitativefood frequency questionnaire dan alat bantu buku foto makanan. Data dikumpulkan oleh peneliti dan tiga orang enumerator dengan latar belakang pendidikan D3 Gizi. Berdasarkan cutoff Gibson (2005), kriteria tingkat kecukupan asupan dikatakan cukup apabila $>77$ persen dari angka kecukupan gizi (AKG) yang dianjurkan dan kategori kurang jika asupan $<77$ persen dari AKG. ${ }^{20}$ Status gizi dikatakan overweight pada cut off International Obesity Task Force (2000) ketika indeks massa tubuh (IMT) $\geq 23$ $\mathrm{kg} / \mathrm{m}^{2}$ dan kategori tidak overweight ketika IMT $<23 \mathrm{~kg} / \mathrm{m}^{2}$. ${ }^{21}$ Pengukuran antropometri berupa penimbangan berat badan dan pengukuran tinggi badan responden. Penimbangan berat badan menggunakan timbangan digital merek 
Gea EB 9350 dan pengukuran tinggi badan menggunakan microtoise merek Gea $2 \mathrm{M}$. Penentuan hipertensi berdasarkan asesmen dan diagnosis dokter. Responden dinyatakan hipertensi apabila tekanan darah sistolik $\geq 140$ $\mathrm{mmHg}$ dan tekanan darah diastolik $\geq 90 \mathrm{mmHg}$ dengan menggunakan tensimeter aneroid merek Onemed. Pengolahan data asupan menggunakan buku Kandungan Asam Lemak Pangan Indonesia, program Microsoft Excel untuk menghitung kandungan asam lemak, dan Nutrisurvey untuk menghitung asupan mineral (kalsium, magnesium, kalium). Analisis data menggunakan uji Chi Square dengan perangkat lunak program statistik SPSS.
HASIL

\section{Karakteristik Responden}

Karakteristik umum responden pada penelitian ini tersaji pada Tabel 1. Hampir semua lansia berjenis kelamin perempuan. Menurut Kementerian Kesehatan RI, istilah lanjut usia diperuntukkan bagi orang yang berusia 60 tahun atau lebih. Proporsi lansia yang berumur 60 tahun ke atas hampir sama dengan lansia umur kurang dari 60 tahun. Tingkat pendidikan lansia lebih banyak yang berpendidikan SMP ke bawah. Sebagian besar (sekitar 70\%) responden memiliki status gizi dengan kategori overweight IMT $\geq 23$ dan tidak hipertensi.

Tabel 1. Karakteristik Responden

\begin{tabular}{lcc}
\hline \multicolumn{1}{c}{ Variabel } & $\mathrm{n}$ & $\%$ \\
\hline $\begin{array}{l}\text { Karakteristik } \\
\text { Jenis kelamin }\end{array}$ & & \\
$\quad$ Laki-laki & 7 & 6,5 \\
$\quad$ Perempuan & 101 & 93,5 \\
Umur & & \\
$\quad<60$ tahun & 53 & 49,1 \\
$\geq 60$ tahun & 55 & 50,9 \\
Pendidikan & & \\
Tidak sekolah & 25 & 23,1 \\
SD & 30 & 27,8 \\
SMP & 20 & 18,5 \\
SMA & 27 & 25 \\
Perguruan tinggi & 6 & 5,6 \\
Status gizi & & \\
IMT $\geq 23$ & 80 & 74 \\
IMT <23 & 28 & 26 \\
Kejadian hipertensi & & \\
Hipertensi & 37 & 34 \\
Tidak hipertensi & 71 & 66 \\
\hline
\end{tabular}


Tingkat Kecukupan Lemak Tidak Jenuh Tunggal, Kalsium, Magnesium, dan Kalium

Data pada Tabel 2 menunjukkan hampir semua lansia mempunyai tingkat kecukupan lemak tidak jenuh tunggal kurang, dan hampir setengah dari total responden memiliki tingkat kecukupan kalsium dan kalium kurang dari AKG, tetapi memiliki tingkat kecukupan magnesium cukup dari AKG.

\section{Tabel 2. Tingkat Kecukupan Lemak Tidak Jenuh Tunggal, Kalsium, Magnesium, dan Kalium pada Lansia}

\begin{tabular}{lcccc}
\hline \multirow{2}{*}{ Tingkat Kecukupan Zat Gizi } & \multicolumn{2}{c}{ Kutegori } \\
\cline { 2 - 5 } & $\mathrm{n}$ & $\%$ & $\mathrm{n}$ & $\%$ \\
\hline Lemak tidak jenuh tunggal & 104 & 96,3 & 4 & 3,7 \\
Kalsium & 88 & 81,5 & 20 & 18,5 \\
Magnesium & 34 & 31,5 & 74 & 68,5 \\
Kalium & 59 & 54,6 & 49 & 45,4 \\
\hline
\end{tabular}

Analisis dilanjutkan dengan menggunakan uji Chi Square untuk melihat hubungan tingkat kecukupan lemak tidak jenuh tunggal, mineral (kalsium, magnesium, kalium), dan status gizi dengan kejadian hipertensi. Berdasarkan Tabel 3 , umumnya lansia $(65,4 \%)$ yang kurang asupan lemak tidak jenuh tunggal tidak menderita hipertensi, namun secara statistik hubungan kecukupan lemak tidak jenuh tunggal dengan kejadian hipertensi tidak signifikan $(p>0,05)$. Sebagian besar responden memiliki asupan kalsium kurang, tetapi asupan kalsium yang kurang tidak berhubungan dengan peningkatan hipertensi dalam penelitian ini $(p>0,05)$. Untuk tingkat kecukupan kalium cukup, lebih dari separuh tidak menderita hipertensi $(63,5 \%)$. Hasil uji ini menunjukkan tidak adanya hubungan tingkat kecukupan kalium dengan kejadian hipertensi $(p>0,05)$.

Umumnya lansia (75\%) yang cukup akan asupan lemak tidak jenuh tunggal, kalsium, kalium, dan magnesium tidak menderita hipertensi. Lansia yang overweight lebih dari setengah tidak menderita hipertensi. Hasil uji ini menunjukkan tidak adanya hubungan antara tingkat kecukupan kalsium dengan kejadian hipertensi $(p>0,05)$. 
Tabel 3. Hubungan Tingkat Kecukupan Lemak Tidak Jenuh Tunggal, Magnesium, Kalium, dan Status Gizi dengan Kejadian Hipertensi pada Lansia

\begin{tabular}{|c|c|c|c|c|c|}
\hline \multirow{3}{*}{ Tingkat Kecukupan Asupan Zat Gizi } & \multicolumn{4}{|c|}{ Kejadian Hipertensi } & \multirow{3}{*}{$p$} \\
\hline & \multicolumn{2}{|c|}{ Hipertensi } & \multicolumn{2}{|c|}{ Tidak Hipertensi } & \\
\hline & $n$ & $\%$ & $\mathrm{n}$ & $\%$ & \\
\hline \multicolumn{6}{|l|}{ Lemak tidak jenuh tunggal } \\
\hline Kurang & 36 & 34,6 & 68 & 65,4 & \multirow{2}{*}{1,000} \\
\hline Cukup & 1 & 25,0 & 3 & 75,0 & \\
\hline \multicolumn{6}{|l|}{ Tingkat kecukupan kalsium } \\
\hline Kurang & 32 & 36,4 & 56 & 63,6 & \multirow{2}{*}{0,480} \\
\hline Cukup & 5 & 25,0 & 15 & 75,0 & \\
\hline \multicolumn{6}{|l|}{ Tingkat kecukupan magnesium } \\
\hline Kurang & 10 & 29,4 & 24 & 70,6 & \multirow{2}{*}{0,616} \\
\hline Cukup & 27 & 36,5 & 47 & 63,5 & \\
\hline \multicolumn{6}{|l|}{ Tingkat kecukupan kalium } \\
\hline Kurang & 19 & 32,2 & 40 & 67,8 & \multirow{2}{*}{0,772} \\
\hline Cukup & 18 & 36,7 & 31 & 63,3 & \\
\hline \multicolumn{6}{|l|}{ Status gizi } \\
\hline Overweight & 29 & 36,2 & 51 & 63,8 & \multirow{2}{*}{0,613} \\
\hline Tidak overweight & 8 & 28,6 & 20 & 71,4 & \\
\hline
\end{tabular}

\section{PEMBAHASAN}

Proporsi responden dengan asupan lemak tidak jenuh tunggal dengan kategori kurang sebagian besar tidak mengalami hipertensi. Hasil ini sesuai dengan penelitian Fikrat yang mengungkapkan bahwa lemak tidak jenuh tunggal/ monounsaturated fat acids (MUFA) tidak memiliki hubungan dengan kejadian hipertensi. ${ }^{22} \mathrm{Hal}$ ini tidak sejalan dengan penelitian Rasmussen yang menyatakan bahwa asupan MUFA memiliki perbedaan yang signifikan terhadap penurunan tekanan darah sistolik dan diastolik. ${ }^{23}$

Berdasarkan hasil wawancara menggunakan semi quantitative-food frequency questionnaire (SQ-FFQ) dengan responden, diperoleh data bahwa hampir semua responden tidak mengonsumsi sumber makanan yang mengandung asam lemak tidak jenuh tunggal yang bersumber dari minyak tumbuh-tumbuhan. Hal itu disebabkan harga yang tidak terjangkau dan ketidaktahuan akan sumber makanan tersebut, sehingga hampir semua responden memiliki tingkat kecukupan lemak tidak jenuh tunggal kurang, yaitu sebanyak 104 orang $(96,3 \%)$.

Analisis hasil yang menunjukkan hubungan tingkat kecukupan kalsium dengan kejadian hipertensi, didukung oleh penelitian Hasna yang membuktikan tidak adanya hubungan antara hipertensi dengan tingkat kecukupan kalsium. ${ }^{15}$ Hasil yang diperoleh berbeda dengan penelitian Primadita, yang menyatakan bahwa asupan kalsium yang cukup memiliki hubungan dengan hipertensi. ${ }^{9}$ Pada keadaan klinis yang berkaitan dengan hiperkalsemia kadar kalsium dalam 
plasma jarang cukup tinggi untuk memengaruhi jantung. ${ }^{23}$ Saat tubuh kekurangan kalsium mengakibatkan turunnya kemampuan jantung memompa darah serta akan memengaruhi tekanan darah. Ketika tubuh kekurangan kalsium dalam darah, maka hormon paratiroid akan membantu pengeluaran kalsium dari tulang yang kemudian masuk ke dalam darah. Hasil penelitian ini menyatakan tidak adanya hubungan kalsium dengan hipertensi, kemungkinan dikarenakan masih tersedianya cadangan kalsium yang cukup dalam tubuh. Selain itu, ada beberapa faktor yang menghambat penyerapan kalsium di usus halus seperti oksalat dan fosfor yang akan menjadi pemicu menurunnya fungsi kalsium dalam penurunan tekanan darah. Faktor genetik juga memengaruhi optimalisasi tubuh dalam menurunkan tekanan darah. ${ }^{24}$

Tekanan darah dipengaruhi oleh penurunan magnesium yang berfungsi dalam aktivitas otot jantung, sehingga apabila jumlah magnesium dalam darah berkurang, maka optimalisasi jantung akan menurun. ${ }^{15} \mathrm{Hasil}$ analisis yang diperoleh pada penelitian ini, didukung oleh penelitian dari Adyana yang menunjukkan bahwa tidak ada hubungan tingkat kecukupan magnesium dan hipertensi. ${ }^{25}$ Berdasarkan analisis ini diperoleh bahwa asupan yang mendukung penurunan tekanan darah yaitu asupan magnesium dengan tingkat kecukupan kategori cukup $(68,5 \%)$. Serat, oksalat, fitat, dan fosfor dapat menyebabkan terhambatnya penyerapan magnesium dalam usus halus, dan dapat menghambat penurunan tekanan darah. Menurunnya penyerapan magnesium juga dipengaruhi oleh faktor stres mental dan fisik. ${ }^{26}$

Jumlah kalium yang meningkat akan menyebabkan natrium di intraseluler berkurang, sehingga berdampak pada turunnya tekanan darah. Meningkatnya konsentrasi kalium dalam intraseluler karena konsumsi kalium dalam jumlah yang banyak mengikat cairan dari bagian ekstraseluler sehingga tekanan darah turun. ${ }^{27}$
Kadar kalium kurang dari 3,5 mEq/L akan menyebabkan hipokalemia sehingga frekuensi denyut jantung melambat. ${ }^{28}$ Peningkatan konsentrasi ion kalium 8-15 $\mathrm{mEq} / \mathrm{L}$ akan menyebabkan kelemahan jantung dan timbulnya irama abnormal jantung. Hasil riset yang dilakukan, didukung oleh penelitian Miftahul yang juga mendapatkan hasil sama yaitu tidak adanya hubungan tingkat kecukupan kalium dengan kejadian hipertensi. ${ }^{29}$ Berbeda dengan hasil penelitian Widyaningrum, yang menyimpulkan ada hubungan asupan kalium dengan kejadian hipertensi. ${ }^{30}$ Penelitian ini menunjukkan tidak adanya hubungan antara tingkat kecukupan kalium dengan hipertensi kemungkinan karena ion kalium dalam tubuh responden masih tercukupi. Selain karena tingkat kecukupan kalium, hal tersebut dapat terjadi karena faktor umur, kebiasaan berolahraga, stres, dan riwayat keluarga. ${ }^{31}$

Overweight dan obesitas berhubungan dengan perubahan struktur jantung seperti peningkatan diameter atrium, dimensi dan massa ventrikel kiri serta peningkatan tekanan darah. Obesitas juga merupakan faktor penyebab terjadinya perubahan preklinis pada jantung, seperti volume overload yang menyebabkan peningkatan tekanan darah, sistem aktivitas simpatetik renin-angiotensin aldosteron, dan transisi sistem pembuluh darah yang menyebabkan hipertensi. ${ }^{32}$ Berdasarkan hasil riset ini diketahui bahwa tidak ada hubungan antara status gizi dengan kejadian hipertensi. Berdasarkan penelitian yang dilakukan oleh Syami status gizi juga tidak memiliki hubungan dengan kejadian hipertensi yang mendukung hasil penelitian penulis, ${ }^{33}$ akan tetapi berdasarkan penelitian hipertensi lansia di Minahasa status gizi memiliki hubungan dengan tekanan darah. ${ }^{19}$

Faktor yang bertanggung jawab terhadap mekanisme hipertensi bukanlah faktor tunggal. ${ }^{34}$ Secara fisiologis ada faktor yang memengaruhi tekanan darah diantaranya volume sekuncup 
dan total peripheral resistance. Apabila terjadi peningkatan salah satu variabel yang tidak terkompensasi maka dapat menyebabkan timbulnya hipertensi. Tubuh memiliki sistem yang berfungsi mencegah perubahan tekanan darah secara akut yang disebabkan oleh gangguan sirkulasi dan mempertahankan stabilitas tekanan darah dalam jangka panjang. Walaupun lebih banyak responden yang memiliki berat badan lebih tetapi tidak hipertensi, kemungkinan dapat disebabkan faktor umur, jenis kelamin, tingkat pendidikan, aktivitas fisik, asupan makan, faktor genetik (keturunan), kebiasaan merokok, dan stres. ${ }^{35}$

Keterbatasan dalam penelitian ini adalah teknik SQ-FFQ yang dilakukan pada subjek penelitian lansia mungkin dapat menyebabkan under atau over-estimate frekuensi dan atau jumlah konsumsi yang lansia informasikan. Memori dalam mengingat pola konsumsi satu bulan lalu bisa saja menurun pada responden lansia sehingga hal ini mungkin menyebabkan belum ditemukannya hubungan asupan lemak tidak jenuh ganda dan mineral-mineral yang diteliti dengan hipertensi secara signifikan.

\section{KESIMPULAN}

Tingkat kecukupan lemak tidak jenuh tunggal, mineral, dan status gizi tidak berhubungan dengan kejadian hipertensi pada lansia di Posbindu PTM Puskesmas Tajur Kota Tangerang kemungkinan disebabkan faktor risiko lain yang berhubungan dengan hipertensi yang tidak dianalisis dalam penelitian ini.

\section{SARAN}

Untuk memenuhi kebutuhan zat gizi mikro lansia, diperlukan peningkatan asupan kalium, magnesium, dan kalsium yang umumnya ditemukan masih rendah pada lansia. Disarankan untuk menggunakan desain case control dengan jumlah sampel yang lebih besar untuk penelitian selanjutnya.

\section{UCAPAN TERIMA KASIH}

Ucapan terima kasih disampaikan kepada para fasilitator Scientific Article Writing (SAWT) Batch II, Program Studi S1 Gizi, FIKES, Universitas Esa Unggul: Khairizka Citra Falupi, S.Gz, M.S,RD, Dudung Angkasa, S.Gz, M.Gizi, RD, Laras Sitoayu, S.Gz, M.Gizi, RD.

\section{DAFTAR PUSTAKA}

1. Chobanian AV, Bakris GL, Black HR, Cushman WC, Green LA, Izzo JL, et al. The Seventh Report of The Joint National Committee on Prevention, Detection, Evaluation, and Treatment of High Blood Pressure: The JNC 7 Report. Journal of The American Medical Association. 2003;289(19):2560-72.

2. Kearney PM, Whelton M, Reynolds K, Muntner P, Whelton PK, He J. Global Burden of Hypertension: Analysis of Worldwide Data. The Lancet. 2005;365(9455):217-23.

3. Badan Penelitian dan Pengembangan Kesehatan, Kementerian Kesehatan RI. Hasil Utama Riset Kesehatan Dasar. Jakarta: Badan Penelitian dan Pengembangan Kesehatan, Kementerian Kesehatan RI; 2018.

4. Ganong W. Buku Ajar Fisiologi Kedokteran. $20^{\text {th }}$ ed. Jakarta: EGC; 2001.

5. Lin PH, Svetkey LP. Nutrition, Lifestyle Factors, and Blood Pressure. Florida: CRC Press; 2012.

6. Agustini Z. Hubungan Asupan Lemak (Lemak Jenuh Tak Jenuh, Kolesterol) dan Natrium terhadap Tekanan Darah terhadap Pasien Hipertensi di Poli Penyakit dalam RSP Batu. Skripsi. Malang: Program Studi IImu Gizi Fakultas Kedokteran Universitas Brawijaya, 2013.

7. Lidyawati, Kartini A. Hubungan Asupan Asam Lemak Jenuh Asam Lemak Tidak Jenuh dan Natrium dengan Kejadian Hipertensi 
pada Wanita Menopouse di Kelurahan Bojongsalaman. J Nutr Coll. 2014;3(4):6129.

8. Jorde $\mathrm{R}$, Bonaa $\mathrm{KH}$. Calcium from Dairy Products, Vitamin D Intake, and Blood Pressure: The Tromso Study. Am J Clin Nutr. 2000;71(6):1530-5.

9. Primadita. Hubungan antaraAsupan Natrium, Kalium, Kalsium, dan Magnesium dengan Hipertensi di Puskesmas Mergangsan Yogyakarta. Skripsi. Yogyakarta: Program Studi Gizi Kesehatan UGM, 2009.

10. Hasanah U. Hubungan antara Asupan Kalsium dan Magnesium dengan Kejadian Hipertensi Pasien Rawat Jalan RSUD Panembahan Senopati Bantul Yogyakarta. Skripsi. Yogyakarta: Program Studi Gizi Universitas Alma Ata, 2016.

11. Astawan M. Cegah Hipertensi dengan Pola Makan. Jakarta: PT. Gramedia Pustaka Utama; 2002.

12. Amran $Y$, Febrianti F, Irawanti L. Pengaruh Tambahan Asupan Kalium dari Diet terhadap Penurunan Hipertensi Sistolik Tingkat Sedang pada Lanjut Usia. Kesmas Natl Public Heal J. 2010;5(3):125-30.

13. Susanti MR. Hubungan antara Asupan Natrium dan Kalium dengan Tekanan Darah pada Lansia di Kelurahan Pajang. Skripsi. Surakarta: Fakultas IImu Kesehatan Universitas Muhammadiyah Surakarta, 2017.

14. Zhao L, Stamler J, Yan LL, Zhou B, Wu Y, Liu $\mathrm{K}$, et al. Blood Pressure Differences between Northern and Southern Chinese: Role of Dietary Factors The International Study on Macronutrients and Blood Pressure. Hypertension. 2004;43(6):1332-7.

15. Putri EHD, Kartini A. Hubungan Asupan Kalium, Kalsium dan Magnesium dengan Kejadian Hipertensi pada Wanita Menopause di Kelurahan Bojongsalaman, Semarang. $J$ Nutr Coll. 2014;3(4):580-6.

16. Listiana L, Krisnasary A, Rizal A. Hubungan Pola Konsumsi Zat Gizi Makro dan Mikro dengan Tekanan Darah pada Penderita Hipertensi. Jurnal Media Kesehatan. 2018;10(2):126-38.

17. Palmer S, Wiliams B. Tekanan Darah Tinggi. Jakarta: Erlangga; 2007.

18. Fathina UA. Hubungan Asupan Sumber Lemak dan Indeks Massa Tubuh (IMT) dengan Tekanan Darah pada Penderita Hipertensi. Skripsi. Semarang: Program Studi Ilmu Gizi Fakultas Kedokteran Universitas Diponegoro, 2007.

19. Adam R, Punuh MI, Kapantow NH. Hubungan antara Status Gizi dengan Kejadian Hipertensi Usia 41-65 Tahun di Desa Sinuian Kecamatan Remboken Kabupaten Minahasa Tahun 2015. Skripsi. Manado: Fakultas Kesehatan Masyarakat Universitas Sam Ratulangi, 2015.

20. Gibson R. Principles of Nutritional Assessment. $2^{\text {nd }}$ ed. New York: Oxford University Press Inc; 2005.

21. Safitri M. Tingkat Asupan Protein, Lemak, Natrium, Serat, Indeks Massa Tubuh (IMT), dan Kejadian Hipertensi pada Kelompok Senam Bugar Lansia di Posbindu Kartini, Pondok Pucung Kota Tangerang Selatan. Skripsi. Jakarta: Program Studi IImu Gizi Universitas Esa Unggul, 2016.

22. Putri FV. Hubungan antara Asupan Lemak Jenuh Asupan Lemak Tidak Jenuh dan Frekuensi Konseling dengan Status Hipertensi di Puskesmas Sentolo I Kabupaten Kulon Progo Tahun 2017. Skripsi. Yogyakarta: Program Studi DIV Gizi Poltekkes Kemenkes Yogyakarta, 2017.

23. Rasmussen BM, Vessby $B$, Uusitupa $M$, Berglund $L$, Pedersen $E$, Riccardi $G$, et al. Effects of Dietary Saturated, 
Monounsaturated, and n-3 Fatty Acids on Blood Pressure in Healthy Subjects. Am J Clin Nutr. 2006;83(2):221-6.

24. Guyton A, Hall J. Buku Ajar Fisiologi Kedokteran. $11^{\text {th }}$ ed. Jakarta: EGC; 2008.

25. Wang L, Manson JE, Buring JE, Lee IM, Sesso HD. Dietary Intake of Dairy Products, Calcium, and Vitamin D and the Risk of Hypertension in Middle-Aged and Older Women. Hypertension. 2008;51:1073-9.

26. Adyana AW, Mintarsih SN, Rahmawati AY. Hubungan antara Asupan Natrium, Kalium, Kalsium dan Magnesium dengan Kejadian Hipertensi pada Remaja di SMA Negeri 10 Kota Semarang. J Ris Gizi. 2016;4(1):1-8.

27. Rolfes S, Pinna K, Whitney E. Water and the Major Mineral. In: Understanding Normal and Clinical Nutrition. $7^{\text {th }}$ ed. USA: Thomson Wadsworth; 2006.

28. Hendrayani C. Hubungan Rasio Asupan Natrium: Kalium dengan Kejadian Hipertensi pada Wanita Usia 25-45 Tahun di Komplek Perhubungan Surabaya. Skripsi. Semarang: Program Studi IImu Gizi Fakultas Kedokteran Universitas Diponegoro, 2009.

29. Yaswir R, Ferawati I. Fisiologi dan Gangguan Keseimbangan Natrium, Kalium, dan Klorida serta Pemeriksaan Laboratorium. Jurnal Kesehatan Andalas. 2012;1(2):80-5.

30. In'am M. Hubungan Tingkat Pengetahuan Orang Tua dengan Status Gizi Anak di
Bawah 5 Tahun di Posyandu Wilayah Kerja Puskesmas Nusukan Surakarta. Skripsi. Surakarta: Program Studi Pendidikan Dokter Fakultas Kedokteran Universitas Muhammadiyah Surakarta, 2016.

31. Widyaningrum AT. Hubungan Asupan Natrium Kalium Magnesium dan Status Gizi dengan Tekanan Darah pada Lansia di Kelurahan Makamhaji Kecamatan Kartasura. Skripsi. Surakarta: Program Studi Gizi Fakultas IImu Kesehatan Universitas Muhammadiyah Surakarta, 2014.

32. Lestari D. Hubungan Asupan Kalium, Kalsium, Magnesium, dan Natrium, Indeks Massa Tubuh, serta Aktifitas Fisik dengan Kejadian Hipertensi pada Wanita Usia 30-40 Tahun. Skripsi. Semarang: Program Studi Ilmu Gizi Fakultas Kedokteran Universitas Diponegoro, 2010.

33. Sung JK, Kim JY. Obesity and Preclinical Changes of Cardiac Geometry and Function. Korean Circ J. 2010;40(2):55-61.

34. Yulianti S, Rokhanawati D. Hubungan Status Gizi dengan Kejadian Hipertensi pada Wanita Lanjut Usia di Posyandu Wira Lestari 6 Wirobrajan Yogyakarta Tahun 2010. Tesis. Yogyakarta: Program Studi Kebidanan Fakultas IImu Kesehatan Universitas Aisyiyah Yogyakarta, 2010.

35. Prodjosudjadi W. Hipertensi: Mekanisme dan Penatalaksanaan. Berkala Neuro Sains. 2000;1(3):133-9. 